

ACTINODUYRA RAMSAYY, Walden 


\title{
ACTINODURA RAMSAYI.
}

\section{Ramsay's Barwing.}

\author{
Actimura ramsayi, Wald. Ann. \& Mag. Nat. Hist. ser. 4, xv. p. 402 (1875).-Hume, Stray Feathers, iii. \\ p. 404 (1875).-Wardlaw Ramsay, Ibis, 1877, p. 464, pl. xiii.-id. Orn. Works of Marquis of \\ Tweeddale, p. 415 \\ Actinodura ramsayi, Hume, Stray Feathers, 1879, p. 97.
}

RAmsay's Barwing was discovered by the gentleman after whom it is named, in the hills of Karen-nee, in Burmah, at a place called Kyai-pho-gyee. He states that he found it frequenting the jungle-covered mountain-streams in the open country of Karen-nee, at an elevation of about 3000 feet, but he did not subsequently meet with it.

The species is a very distinct one, easily recognizable by its ochraceous coloration; and I add herewith the original description given by the late Marquis of Tweeddale.

"Under surface from chin to vent clear ochreous buff, somewhat darker on the chin and throat; upper surface cinereous olive; forehead almost ferruginous; crown and crest, with the nape, like the back, but tinged with ferruginous ; most of the dorsal feathers traversed by faint, yet distinct, narrow dark brown bands or lines, which on the upper tail-coverts are more closely set together and very conspicuous; lores and cheeks dark brown, almost black; sides of the head behind the eyes and some of the lateral crest-plumes ashy, without any ferruginous tinge; eyelids white; primaries narrowly barred with black on their outer webs up to their insertion, also the minor coverts; all the rectrices olive-brown, like the tertiaries, and distinctly barred with numerous well-defined narrow black bands; all but middle pair broadly tipped with white; under tail-coverts and flanks somewhat darker than remainder of under surface. Wing 3.50 inches, tarsus $1 \cdot 12$, tail 5 ; bill from forehead $0 \cdot 87$."

Captain Wardlaw Ramsay has given the soft parts of the species as follows :- " Iris light hair-brown, bill horny brown, legs slaty brown."

In the Plate I have given a life-sized illustration of the male and female, drawn from the typical pair lent to me by Captain Wardlaw Ramsay. 


\section{$2 \mathrm{BHL}$ Biodiversity Heritage Library}

Gould, John. 1882. "Ramsay's Bee-wing, Actinodura ramsayi [PI. 59]." The Birds of Asia 3(XXXIII), -. https://doi.org/10.5962/p.323269.

View This Item Online: https://www.biodiversitylibrary.org/item/118635

DOI: https://doi.org/10.5962/p.323269

Permalink: https://www.biodiversitylibrary.org/partpdf/323269

\section{Holding Institution}

Smithsonian Libraries

\section{Sponsored by}

Smithsonian Institution Libraries

\section{Copyright \& Reuse}

Copyright Status: Not in copyright

This document was created from content at the Biodiversity Heritage Library, the world's largest open access digital library for biodiversity literature and archives. Visit BHL at https://www.biodiversitylibrary.org. 